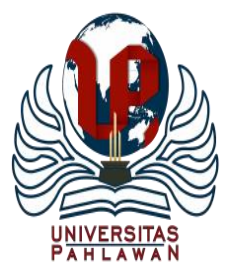

Edukatif : Jurnal Ilmu Pendidikan Volume 3 Nomor 5 Tahun 2021 Halm 3123 - 3130

EDUKATIF: JURNAL ILMU PENDIDIKAN

Research \& Learning in Education

https://edukatif.org/index.php/edukatif/index

\title{
Media Pembelajaran dan Minat Belajar Fisika Siswa SMP Dalam Pembelajaran Jarak Jauh
}

\author{
Sutri Novika $^{1 凶}$, Rofiqoh Hasan Harahap $^{2}$, Emelia Rahmadany ${ }^{3}$ \\ Universitas Muslim Nusantara Al Washliyah, Indonesia ${ }^{1,2,3}$

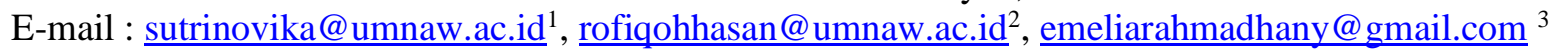

\begin{abstract}
Abstrak
Pembelajaran jarak jauh dalam jaringan (daring) dan luar jaringan (luring) adalah dua pendekatan pembelajaran dari rumah. Artikel ini bertujuan untuk mendeskripsikan pemanfaatan media pembelajaran jarak jauh dan minat siswa dalam pembelajaran fisika menggunakan media pembelajaran daring dan lurimg di SMP Siti Hajar. Subyek dipilih dengan menggunakan purposive sampling. Instrumen pengumpulan data adalah kuesioner dan wawancara. Hasil penelitian menunjukkan bahwa guru menggunakan platform pembelajaran daring (seperti Microsoft Teams dan Zoom) dan media pembelajaran luring. Berdasarkan hasil tanggapan pada kuesioner, analisis data menunjukkan bahwa minat siswa terhadap pembelajaran fisika dengan menggunakan media pembelajaran jarak jauh daring dan luring berada pada kategori baik. Dan beda rata-rata skor minat belajar siswa dianalisis dengan uji paired sample t-test. Meskipun koneksi jaringan internet sering lambat atau tidak tersedia dan mempengaruhi konsentrasi belajar siswa, analisis data menunjukkan bahwa minat siswa untuk belajar fisika dari rumah menggunakan media pembelajaran daring lebih tinggi daripada belajar fisika menggunakan media luring.
\end{abstract}

Kata Kunci: minat siswa, pembelajaran jarak jauh, media pembelajaran

\begin{abstract}
Remote learning with internet access (online) and without internet access (offline) are two approaches to learning from home. This article aimed to describe the use of remote learning media and student's interest in learning physics using online and offline learning media in SMP Siti Hajar. Subjects were selected using purposive sampling. Data gathering instruments are questionnaires and interviews. The result showed that teachers used online learning platforms (like Microsoft Teams and Zoom) and offline learning media. Based on the questionnaires' responses, the analysis data showed that student's interest in physics learning using online and offline remote learning media are in a good category. And the difference in the mean score of student's interest was analyzed by paired sample t-test. Even though online access was often slow or unavailable and it affected student concentration, the analysis showed that student's interest in learning physics at home using online media is higher than using offline media.
\end{abstract}

Keywords: student's interest, remote learning, learning media

Copyright (c) 2021 Sutri Novika, Rofiqoh Hasan Harahap, Emelia Rahmadany

$\triangle$ Corresponding author:

Email : sutrinovika@umnaw.ac.id

DOI : https://doi.org/10.31004/edukatif.v3i5.1078

ISSN 2656-8063 (Media Cetak)

ISSN 2656-8071 (Media Online)

Edukatif : Jurnal Ilmu Pendidikan Vol 3 No 5 Tahun 2021 p-ISSN 2656-8063 e-ISSN 2656-8071 
3124 Media Pembelajaran dan Minat Belajar Fisika Siswa SMP Dalam Pembelajaran Jarak Jauh - Sutri Novika, Rofiqoh Hasan Harahap, Emelia Rahmadany

DOI: https://doi.org/10.31004/edukatif.v3i5.1078

\section{PENDAHULUAN}

Situasi pembelajaran di masa pandemi covid-19 menuntut siswa untuk aktif belajar mandiri, dan guru dituntut untuk menyajikan pembelajaran secara daring. Saat ini cukup tersedia media pembelajaran daring yang dapat dimanfaatkan siswa untuk belajar di rumah, beberapa diantaranya adalah: belajar.kemendikbud.go.id, tve.kemendikbud.go.id, rumahbelajar.id, dan bahan ajar multimedia medukasi.kemendibud.go.id/medukasi. Namun pelaksanaan pembelajaran jarak jauh tidak selalu berjalan mulus, khususnya dalam pembelajaran fisika. Di samping itu, terdapat masalah tidak semua siswa memiliki smartphone pribadi, dan internet yang tidak stabil, sehingga pembelajaran yang diberikan guru melalui aplikasi e-learning tidak semua siswa dapat mengikuti pembelajaran daring. Baety \& Munandar (2021:880) dalam penelitiannya menemukan bahwa ada $63 \%$ responden menyatakan bahwa pelaksanaan pembelajaran daring belum efektif, dan efektifitas dari pembelajaran daring dipengaruhi oleh faktor ekonomi (38\%), faktor sosial (30\%), faktor Kesehatan (19\%) dan faktor kepribadian (13\%). Kesulitan dalam proses pembelajaran online yang di alami oleh mahasiswa terletak pada efektifitas proses belajar mengajar dan juga faktor kendala teknis seperti jaringan internet yang tidak stabil, kuota yang terbatas, faktor lingkungan tempat tinggal mahasiswa dan juga Interaksi yang minim ketika proses pembelajaran online berlangsung (Turmuzi , 2021:908). Sementara itu Maulidina \& Bhakti (2020:250) menyimpulkan bahwa pembelajaran secara langsung memang metode yang paling tepat dilakukan untuk pelajaran Fisika.

Berdasarkan Surat Edaran Kemendikbud No 15 Tahun 2020 tentang Pedoman Penyelenggaraan Belajar Dari Rumah Dalam Masa Darurat Penyebaran Corona Virus Disease (Covid-19), belajar dari rumah (BDR) dilaksanakan dengan Pembelajaran Jarak Jauh (PJJ) yang dibagi ke dalam 2 pendekatan, yaitu pembelajaran jarak jauh dalam jaringan (daring) dan pembelajaran jarak jauh luar jaringan (luring). Dalam pelaksanaan pembelajaran jarak jauh, satuan pendidikan dapat memilih pendekatan (daring atau luring atau kombinasi keduanya) sesuai dengan ketersediaan dan kesiapan sarana dan prasarana.

Media memiliki peranan yang sangat penting dalam pembelajaran jarak jauh. Tanpa media, kegiatan belajar mengajar tidak bisa dilaksanakan. Guru dan peserta didik harus mampu menggunakan dan memanfaatkan teknologi informasi dan komunikasi (TIK) dengan baik sebagai sumber belajar. Guru memiliki peran memfasilitasi pembelajaran jarak jauh secara during maupun luring yang disesuaikan dengan kondisi siswa. Dalam pembelajaran jarak jauh guru harus siap menghadapi tantangan menggunakan model dan media pembelajaran yang sesuai dengan pembelajaran jarak jauh, karena guru harus memenuhi dua kategori yaitu memiliki capability dan loyality (Hasyim, 2014). Menurut Miftah (2014:1), media pembelajaran penting untuk mendukung belajar mengajar dengan media Internet, jaringan komputer, maupun komputer standalone, dan pemanfaatan media pembelajaran perlu dikaitkan dengan kebutuhan dan karakteristik siswa. Tafonao (2018:1) berpendapat bahwa media pembelajaran dapat membuat proses belajar mengajar lebih efektif dan efesien serta terjalin hubungan baik antara guru dengan peserta didik. Nursyam (2019:818), dalam penelitiannya menyimpulkan bahwa pembelajaran dengan menggunakan media berbasis teknologi informasi dapat meningkatkan minat belajar siswa. Pemilihan media pembelajaran penting untuk menumbuhkan minat belajar siswa di tengah suasana pandemik ini. Dimana aktivitas belajar siswa tidak dapat secara langsung dilihat oleh guru. Dengan adanya minat untuk belajar yang tinggi, diharapkan dapat meningkatkan prestasi belajar siswa. Adam \& Syastra (2015:90) dalam penelitiannya menyimpulkan bahwa pemanfataan media pembelajaran berbasis teknologi informasi bagi siswa kelas X SMA Ananda Batam sebesar 76,94\% dari nilai yang diharapkan. Namun, sebagian besar guru tidak menyadari bahwa kehadiran media dalam mengajar membawa dampak besar untuk meningkatkan motivasi dan kenyamanan siswa (Tamrin et al., 2017). Sementara itu, guru perlu memiliki pengetahuan dan motivasi untuk membantu perkembangan pembelajaran siswa mereka secara optimal (Keller et al., 2017). 
Berdasarkan uraian di atas, rumusan tujuan penelitian ini adalah untuk mendeskripsikan media pembelajaran yang digunakan siswa SMP Siti Hajar dalam pembelajaran jarak jauh dan minat belajar siswa terhadap media yang digunakan.

\section{METODE PENELITIAN}

Lokasi penelitian adalah SMP Siti Hajar. Subjek sumber data dalam penelitian ini adalah guru fisika dan siswa. Subjek dipilih secara purposive. Sampling purposive adalah Teknik penentuan sampel dengan pertimbangan tertentu (Sugiono, 2015:124). Dimana subjek dipilih berdasarkan kriteria berikut: Guru yang mengajar fisika dan mempunyai waktu yang memadai untuk dimintai informasi, dan siswa yang diambil adalah siswa dari guru tersebut yang berjumlah 36 orang siswa. Teknik pengumpulan data yang digunakan dalam penelitian ini yaitu: wawancara dan kuesioner. Wawancara dilakukan kepada guru fisika secara langsung untuk memperoleh informasi mengenai pembelajaran jarak jauh selama pandemi. Pokok masalah yang menjadi bahan pertanyaan adalah media pembelajaran yang digunakan dalam pembelajaran jarak jauh dan minat siswa terhadap media pembelajaran. Pengisian kuesioner dilakukan oleh siswa dengan menggunakan google form dan aplikasi WhatsApp. Kuesioner yang digunakan dalam penelitian ini adalah kuesioner untuk mengetahui minat belajar siswa, yang dibuat berdasarkan indikator minat belajar menurut slameto (dalam Uno. 2021:49), yaitu perasaan senang, perhatian, kepuasan, ketertarikan, keterikatan, dan keterlibatan. Skala yang digunakan pada angket adalah skala Likert dengan 5 (lima) pilihan jawaban, dan kuesioner berupa survey. Sebelum kuesioner disebarkan, terlebih dahulu dilakukan uji validitas dan reliabilitas, dan butir pertanyaan yang digunakan adalah butir pertanyaan yang sudah melewati uji validitas dan reliabelitas.

Analisa perbedaan rata-rata minat belajar siswa menggunakan media daring dan luring menggunakan Uji-t berpasangan. Uji homogenitas dalam penelitian ini menggunakan uji-F, dan Uji normalitas menggunakan uji Lilliefors.

\section{HASIL DAN PEMBAHASAN PENELITIAN}

\section{Media Pembelajaran Jarak Jauh}

Media pembelajaran jarak jauh dalam jaringan (daring) adalah media pembelajaran yang membutuhkan jaringan internet ketika aktivitas belajar berlangsung. Pembelajaran fisika jarak jauh di SMP Siti Hajar dilakukan tatap muka secara online dengan menggunakan flatform video conference Zoom Meeting. Selain itu, aktivitas pembelajaran juga dilakukan tanpa tatap muka yaitu kelas daring. Media kelas daring yang digunakan ialah Microsoft Teams. Guru menggunakan Microsoft Teams sebagai alat untuk membagikan materi pembelajaran dan membuat kuis disetiap akhir pembelajaran.

Penggunaan media pembelajaran dalam jaringan tidak lepas dari masalah, permasalahan yang utama dalam pembelajaran jarak jauh dalam jaringan adalah sinyal internet. Hal ini berdasarkan hasil wawancara dengan guru yang menjawab: jaringan internet, listrik mati, dan perangkat yang error. Dan hasil wawancara dengan 34 siswa, 70\% siswa menjawab sinyal internet, 30\% menjawab kurang memahami materi. Sinyal internet yang buruk mengakibatkan penjelasan guru pada Zoom Meeting menjadi terputus-putus, sehingga siswa menjadi tidak fokus mendengar penjelasan materi dari gurunya. Hal ini mengakibatkan siswa mengalami kesulitan dalam memahami materi. Untuk mengatasi permasalah ini, upaya yang dilakukan oleh Guru fisika di SMP Siti Hajar adalah dengan membagikan rekaman kegiatan belajar tatap muka dengan Zoom Meeting kepada siswa, sehingga guru mengharapkan siswa dapat mengulang kembali pelajaran dan melakukan review terhadap materi yang dipelajari. Hal ini berdasarkan hasil wawancara dengan Ibu Nisa yang mengatakan bahwa "Anak-anak tidak ikut, atau jaringannya lelet, siswanya selalu tu 'Bu, kirimlah apanya rekamannya'.. langsung kita kirim dari google drive kan, jadi anak anak bisa melihat lagi, mereka review" (Khairun Nisa Marwan, wawancara 3 Juni 2021). 
Selain media pembelajaran tatap muka dan kelas daring, juga ada media belajar berbasis website. Media pembelajaran sains berbasis web memiliki potensi untuk meningkatkan tingkat kemandirian belajar dan hasil belajar siswa SMP (IKHSAN et al., 2019). Namun, media belajar berbasis website kurang dimanfaatkan oleh siswa SMP Siti Hajar, sebagian besar siswa hanya belajar dari video dan e-modul yang diberikan guru fisika. Dari hasil wawancara terhadap 27 orang siswa, 7 orang siswa yang menjawab belajar dirumah dengan mengakses website belajar online. Website yang diakses siswa tersebut adalah belajar.kemdikbud, rumahbelajar, medukasi.kemdikbud, brainly, dan ruang guru. Dan 20 orang siswa mengakui hanya belajar dari video dan e-modul yang diberikan guru fisika.

Hal ini sejalan dengan hasil wawancara terhadap guru fisika, yang tidak menggunakan media pembelajaran berbasis website sebagai media pembelajaran. "Tidak ada, karena media kita selalu buat sendiri, karena tuntutan sekolah juga gurunya harus kreatif, jadi kalau pun nengok yang nengok gitu Buk, tapi nanti dibuat sendiri disekolah.." (Khairun Nisa Marwan, wawancara 3 Desember 2020).

Media pembelajaran jarak jauh luar jaringan (luring) adalah media yang dapat digunakan siswa untuk melakukan aktivitas belajar tanpa terhubung dengan jaringan internet. Guru Fisika di SMP Siti Hajar memfasilitasi siswa dengan memberikan e-modul mandiri/bahan dan video pembelajaran. Kedua media pembelajaran ini dibagikan guru sehari sebelum pertemuan dimulai. Selain itu, media pembelajaran luar jaringan yang digunakan adalah alat peraga yang dapat diperoleh siswa dari lingkungan sekitarnya atas arahan dari guru.

Dari hasil wawancara dengan guru, diketahui bahwa Video pembelajaran adalah media pembelajaran yang sering digunakan dalam pembelajaran fisika. Hal ini sejalan dengan pendapat Miftah (2013), yaitu media berperan penting dalam memfasilitasi peserta didik, dan penyajiannya disesuaikan dengan tujuan pembelajaran yang ditetapkan, sehingga sangat membantu pebelajar lebih memahami hal yang dipelajari. Ada banyak materi fisika yang susah untuk dipahami siswa bila tidak ditunjukkan langsung secara visual dan audio. Jika dalam kegiatan belajar mengajar di kelas, guru dapat langsung memperagakannya langsung dikelas bagaimana fenomena fisika atau bagaimana menyelesaikan soal fisika dengan menggunakan rumus. Dalam pembelajaran jarak jauh solusi yang tepat adalah video pembelajaran. Hal ini juga sejalan dengan hasil survey terhadap 36 siswa, yang dapat dilihat pada tabel 1.

Tabel 1

Tanggapan Siswa Terhadap Media Pembelajaran Luring Yang Disukai

\begin{tabular}{|c|c|c|c|c|c|c|c|c|c|c|}
\hline \multirow{2}{*}{ Kategori } & \multicolumn{2}{|c|}{ Televisi } & \multicolumn{2}{|c|}{$\begin{array}{l}\text { Modul } \\
\text { Mandiri }\end{array}$} & \multicolumn{2}{|c|}{ Buku Fisika } & \multicolumn{2}{|c|}{ Alat Peraga } & \multicolumn{2}{|c|}{$\begin{array}{c}\text { video } \\
\text { pembelajaran }\end{array}$} \\
\hline & frekuensi & $\%$ & frekuensi & $\%$ & frekuensi & $\%$ & frekuensi & $\%$ & frekuensi & $\%$ \\
\hline $\begin{array}{l}\text { Sangat Tidak } \\
\text { Suka }\end{array}$ & 0 & 0 & 5 & 14 & 2 & 5 & 1 & 3 & 0 & 0 \\
\hline Tidak Suka & 7 & 19 & 9 & 25 & 10 & 28 & 13 & 36 & 0 & 0 \\
\hline Cukup Suka & 16 & 44 & 16 & 44 & 18 & 50 & 18 & 50 & 6 & 17 \\
\hline Suka & 11 & 31 & 6 & 17 & 6 & 17 & 4 & 11 & 23 & 64 \\
\hline Sangat & 2 & 6 & 0 & 0 & 0 & 0 & 0 & 0 & 7 & 19 \\
\hline Total & 36 & 100 & 36 & 100 & 36 & 100 & 36 & 100 & 36 & 100 \\
\hline
\end{tabular}

Dari tabel 1, dapat dilihat bahwa tidak ada siswa yang tidak menyukai media pembelajaran fisika berupa video. Sementara itu, siswa cukup menyukai buku fisika sebanyak 50\% dan $44 \%$ untuk modul belajar mandiri yang diberikan guru sebagai media belajar di rumah. Jika sumber belajar yang selalu digunakan adalah buku, maka siswa cepat bosan dan sulit memahami materi(Puspitarini \& Hanif, 2019) 
3127 Media Pembelajaran dan Minat Belajar Fisika Siswa SMP Dalam Pembelajaran Jarak Jauh - Sutri Novika, Rofiqoh Hasan Harahap, Emelia Rahmadany

DOI: https://doi.org/10.31004/edukatif.v3i5.1078

\section{Minat Belajar}

Data minat siswa belajar fisika dengan menggunakan media daring ( zoom meeting dan Microsoft Teams) dan dengan media luring ( modul fisika, buku fisika, dan video) dianalis dengan membaginya menjadi empat kategori. Penentuan interval skor ditentukan dengan skor minimal, kuartil 1, median, kuartil 3, dan skor maksimal. Dari hasil perhitungan skor 16 item pertanyaan pada kuesioner, diperoleh skor minimal $=16$, skor maksimal $=80$, median $=48$, kuartil $1=32$, dan kuartil $3=64$. Sehingga frekuensi kategori skor minat belajar dapat dilihat pada tabel 1. Sedangkan hasil analisis deskripsi statistik data minat belajar siswa dengan menggunakan software SPSS dapat dilihat pada tabel 2.

Tabel 2

Kategori Minat Belajar Siswa dengan Menggunakan Media Daring dan Luring

\begin{tabular}{lccccc}
\hline & Interval & \multicolumn{2}{c}{ Media Daring } & \multicolumn{2}{c}{ Media Luring } \\
\cline { 3 - 6 } \multicolumn{1}{c}{ Kategori } & Skor & Frekuensi & Presentase $\%$ & Frekuensi & Presentase \% \\
\hline Sangat Tinggi & $64-79$ & 10 & 28 & 1 & 3 \\
\hline Tinggi & $48-63$ & 22 & 61 & 26 & 72 \\
\hline Rendah & $32-47$ & 4 & 11 & 8 & 22 \\
\hline Sangat Rendah & $16-31$ & 0 & 0 & 1 & 3 \\
\hline Total & & 36 & 100 & 100 & 36 \\
\hline
\end{tabular}

Tabel 3

Statistik Minat Belajar Fisika Siswa

\begin{tabular}{lrrr}
\hline & & Media_Daring & Media_Luring \\
\hline $\mathrm{N}$ & Valid & 36 & 36 \\
\cline { 2 - 4 } & Missing & 0 & 0 \\
\hline Mean & 57.1667 & 51.2222 \\
\hline Median & 56.5000 & 51.5000 \\
\hline Std. Deviation & 8.36148 & 7.77583 \\
\hline Variance & 69.914 & 60.463 \\
\hline Minimum & 37.00 & 29.00 \\
\hline Maximum & 74.00 & 65.00 \\
\hline Sum & 2058.00 & 1844.00 \\
\hline
\end{tabular}

Berdasarkan tabel 2, diketahui sebanyak 28\% skor minat belajar siswa berkategori sangat tinggi dengan menggunakan media belajar daring, dan dengan menggunakan media luring hanya 3\%. Skor minat belajar dengan menggunakan media luring berkategori rendah sebanyak $22 \%$ dan $11 \%$ belajar dengan media daring. Sementara itu, dari tabel 3 dapat diketahui bahwa rata-rata skor minat belajar adalah berkategori tinggi, dapat disimpulkan fasilitas dirumah siswa medukung pembelajaran. Faktor utama pendukung guru guna meningkatkan kembali minat belajar peserta didik adalah dengan memanfaatkan fasilitas rumah yang mendukung pembelajaran dan sarana belajar (Marwa Marwa et al., 2020). Selain itu tingginya minat belajar siswa juga dapat diakibatkan oleh guru yang berkompeten di bidangnya. Dari tabel 3 juga dapat dilihat siswa dengan menggunakan media daring lebih tinggi dibandingkan dengan minat belajar siswa dengan menggunakan media luring, yaitu 57,1667 dan 51,2222. Artinya minat belajar siswa lebih tinggi dengan menggunakan media daring dibandingkan dengan menggunakan media luring.

Uji Normalitas dan Homogenitas

Analisa uji normalitas data minat belajar siswa dengan menggunakan media daring dan luring menggunakan uji-F, untuk menerima atau menolak $H_{0}$ dengan cara membandingkan $L_{\text {hitung }}$ dengan $L_{\text {kritis }}$ 
3128 Media Pembelajaran dan Minat Belajar Fisika Siswa SMP Dalam Pembelajaran Jarak Jauh - Sutri Novika, Rofiqoh Hasan Harahap, Emelia Rahmadany

DOI: https://doi.org/10.31004/edukatif.v3i5.1078

yang diambil dari daftar nilai kritis untuk uji Lilliefors untuk taraf nyata $\alpha=0,05$. Jika $L_{\text {hitung }}>L_{\text {kritis }}$, maka tolak $H_{0}$ (Kadir:107). Hasil Analisa uji normalitas dapat dilihat pada tabel 3.

Tabel 4

Hasil Uji Normalitas

\begin{tabular}{lcc}
\hline \multirow{2}{*}{$L_{\text {kritis }}$} & \multicolumn{2}{c}{$L_{\text {hitung }}$} \\
\hline 0,1476 & Media Daring & Media Luring \\
\hline
\end{tabular}

Dari tabel 4, diketahui bahwa $L_{\text {hitung }}<L_{\text {kritis }}$ untuk media daring dan media luring, sehingga $H_{0}$ diterima, atau data minat belajar dengan kedua media tersebut berdistribusi normal. Selanjutnya uji homogenitas dari kedua data minat belajar menggunakan uji $F$ dengan taraf nyata $\alpha=0,05$. Diperoleh $F_{\text {hitung }}=1,1563$, dan $F_{\text {tabel }}=F_{(0,05)(35: 35)}=1,76$. Hal ini berarti $F_{\text {hitung }}<F_{\text {tabel }}$, maka $H_{0}$ diterima atau kedua kelompok data tersebut mempunyai varians sama atau homogen.

Uji Hipotesis

Setelah dilakukan uji normalitas dan homogenitas, dan didapatkan bahwa data berdistribusi normal dan homogen. Selanjutnya uji hipotesis dapat kita lakukan. Hasil analisa uji t berpasangan diperoleh dengan menggunakan software SPSS dapat dilihat pada tabel 5 dan tabel 6.

Tabel 5

Paired Samples Correlations

\begin{tabular}{|c|c|c|c|c|}
\hline & & $\mathrm{N}$ & Correlation & Sig. \\
\hline Pair 1 & $\begin{array}{l}\text { Media_Daring \& } \\
\text { Media_Luring }\end{array}$ & 36 & .667 & .000 \\
\hline
\end{tabular}

Tabel 6

Paired Samples Test

Paired Differences

\begin{tabular}{|c|c|c|c|c|c|c|c|c|}
\hline & \multirow[b]{2}{*}{ Mean } & \multirow{2}{*}{$\begin{array}{c}\text { Std. } \\
\text { Deviation }\end{array}$} & \multirow{2}{*}{$\begin{array}{l}\text { Std. Error } \\
\text { Mean }\end{array}$} & \multicolumn{2}{|c|}{$\begin{array}{l}\text { 95\% Confidence Interval } \\
\text { of the Difference }\end{array}$} & \multirow[b]{2}{*}{$\mathrm{t}$} & \multirow[b]{2}{*}{ df } & \multirow{2}{*}{$\begin{array}{l}\text { Sig. }(2- \\
\text { tailed })\end{array}$} \\
\hline & & & & Lower & Upper & & & \\
\hline $\begin{array}{c}\text { Pair } 1 \text { Media_Daring - } \\
\text { Media_Luring }\end{array}$ & 5.94444 & 6.60711 & 1.10119 & 3.70892 & 8.17997 & 5.398 & 35 & .000 \\
\hline
\end{tabular}

Uji hipotesis ini adalah uji dua pihak, oleh karena itu $t_{\text {tabel }}=t_{(0,025 ; 35)}=2,023$. Daerah penerimaan $H_{0}$ adalah $-2,023<t_{\text {hitung }}<2,023$. Dari tabel 5 diperoleh informasi $t_{\text {hitung }}=5,398$. Sehingga $t_{\text {hitung }}>t_{\text {tabel }}$. Dengan demikian $t_{\text {hitung }}$ berada di luar daerah penerimaan, dan $H_{0}$ ditolak. Maka $H_{1}$ diterima, terdapat perbedaan minat belajar siswa dengan menggunakan media daring dan media luring. Namun hubungan kedua minat belajar ini tidak bersifat signifikan. Hal ini dapat dilihat dari tabel 5, dimana koefisien korelasi skor minat belajar menggunakan media daring dan luring adalah 0,667.

Berdasarkan paparan hasil analisis media belajar dan minat belajar, suasana kegiatan belajar mengajar yang aktif dan menyesuaikan media dengan kebutuhan dan kondisi siswa menunjukkan minat belajar siswa yang tinggi. Berbeda dengan penelitian sebelumnya yang menunjukkan bahwa bahwa pembelajaran daring pada masa pandemi COVID-19 sangat berpengaruh terhadap minat belajar siswa (Yunitasari \& Hanifah, 2020: 232). Meskipun pembelajaran jarak jauh dalam jaringan siswa sering tidak fokus memahami penjelasan guru dikarenakan masalah jaringan internet, minat belajar siswa menggunakan media daring tersebut tetap tinggi/positif. Hal ini dapat dipengaruhi oleh siswa yang sudah mulai terbiasa dengan pembelajaran jarak jauh. Adanya perbedaan minat belajar dengan menggunakan media daring dan luring bukan berarti kedua media ini 
3129 Media Pembelajaran dan Minat Belajar Fisika Siswa SMP Dalam Pembelajaran Jarak Jauh - Sutri Novika, Rofiqoh Hasan Harahap, Emelia Rahmadany

DOI: https://doi.org/10.31004/edukatif.v3i5.1078

dapat dipisahkan. Pembelajaran jarak jauh seharusnya tetap menggunakan kedua media tersebut secara bersamaan. Sejalan dengan hasil penelitian Maryani \& Sopiansah (2019) variasi penggunaan media berpengaruh terhadap minat belajar siswa

\section{KESIMPULAN}

Pembelajaran fisika jarak jauh dilakukan secara daring dan luring. Media pembelajaran dan kemampuan guru dalam memanfaatkan beberapa media daring yang cukup banyak tersedia dengan berbagai kelebihan dan kelemahan, serta kreatifitas guru dalam membuat media pembelajaran berupa modul yang menarik dan video pembelajaran sangat penting dalam pembelajaran jarak jauh. Terdapat perbedaan rata-rata skor minat belajar dengan menggunakan media daring dan luring, dimana minat belajar siswa dengan menggunakan media daring lebih tinggi dibandingkan dengan menggunakan media luring. Secara umum dapat dikatakan minat belajar siswa dalam pembelajaran jarak jauh ini sudah tinggi.

\section{DAFTAR PUSTAKA}

Adam, S., \& Syastra, M. T. (2015). Pemanfaatan Media Pembelajaran Berbasis Teknologi Informasi bagi Siswa Kelas X SMA Ananda Batam. 3(2), 78-90.

http://ejournal.upbatam.ac.id/index.php/cbis/article/view/400

Baety, D. N., \& Munandar, D. R. (2021). Analasis Efektifitas Pembelajaran Daring Dalam Menghadapi Wabah Pandemi Covid-19. EDUKATIF: Jurnal Ilmu Pendidikan, 3(3), 880-889. https://doi.org/https://doi.org/10.31004/edukatif.v3i3.476

Hasyim, M. (2014). Penerapan Fungsi Guru Dalam Proses Pembelajaran. Auladuna, 1(2), 265-276. http://journal.uin-alauddin.ac.id/index.php/auladuna/article/view/556

IKHSAN, J., AKHYAR, M., \& NAIS, M. K. (2019). The Effects of Science-On-Web Learning Media on Junior High School Students' Learning Independency Levels and Learning Outcomes. Journal of Turkish Science Education, 16(2), 231-239. https://www.tused.org/index.php/tused/article/view/185

Kadir. (2010). Statistika Untuk Penelitian Ilmu-Ilmu Sosial (Juredi (ed.)). Rosemata Sampurna.

Keller, M. M., Neumann, K., \& Fischer, H. E. (2017). The Impact of Physics Teachers' Pedagogical Content Knowledge andMotivation on Students' Achievement and Interest. Journal of Research in Science Teaching, 54(5), 586-614. https://doi.org/10.1002/tea.21378

Kementerian Pendidikan Dan Kebudayaan. (2020). Pedoman Penyelenggaraan Belajar Dari Rumah Dalam Masa Darurat Penyebaran Corona Virus Disease (Covid-19). In Surat Edaran Nomor 15 Tahun $202 O$ (Issue 021, pp. 1-20). https://www.kemdikbud.go.id/main/files/download/27bdb5850ac3939

Marwa Marwa, Munirah, M., Angriani, A. D., Suharti, S., Sriyanti, A., \& Rosdiana, R. (2020). Peran Guru dalam Meningkatkan Minat Belajar Peserta Didik Kelas IV pada Masa Pandemi Covid-19. Jurnal Pendidikan Dasar Islam, 7(2), 215-227.

http://journal.uin-alauddin.ac.id/index.php/auladuna/article/view/17900

Maryani, L., \& Sopiansah, V. A. (2019). Minat Belajar Siswa dengan Variasi Penggunaan Media Pembelajaran (Survey pada Siswa Jurusan Akuntansi di SMK Negeri 3 Bandung). Jurnal Pendidikan Teknologi Informasi Dan Komunikasi, 5(1), 63-69.

https://doi.org/https://doi.org/10.31980/jpetik.v5i1.473

Miftah, M. (2013). Fungsi dan Peran Media Pembelajaran sebagai Upaya Peningkatan Kemampuan Belajar Siswa. KWANGSAN Jurnal Teknologi Pendidikan, 1(2). https://doi.org/https://doi.org/10.31800/jtp.kw.v1n2.p95--105

Miftah, M. (2014). Pemanfaatan Media Pembelajaran untuk Peningkatan Kualitas Belajar Siswa. KWANGSAN, 2(1), 1-11.

https://jurnalkwangsan.kemdikbud.go.id/index.php/jurnalkwangsan/article/view/11/10 
3130 Media Pembelajaran dan Minat Belajar Fisika Siswa SMP Dalam Pembelajaran Jarak Jauh - Sutri Novika, Rofiqoh Hasan Harahap, Emelia Rahmadany

DOI: https://doi.org/10.31004/edukatif.v3i5.1078

Nurmaulidina, S., \& Bhakti, Y. B. (2020). Pengaruh Media Pembelajaran Online Dalam Pemahaman Dan Minat Belajar Siswa Pada Konsep Pelajaran Fisika. ORBITA: Jurnal Kajian, Inovasi Dan Aplikasi Pendidikan Fisika, 6(2), 248-251. https://doi.org/10.31764/orbita.v6i2.2592

Nursyam, A. (2019). Peningkatan Minat Belajar Siswa Melalui Media Pembelajaran Berbasis Teknologi Informasi Media. EKSPOSE: Jurnal Penelitian Hukum Dan Pendidikan, 18(1), 811-819. https://doi.org/http://dx.doi.org/10.30863/ekspose.v18i1.371

Puspitarini, Y. D., \& Hanif, M. (2019). Using Learning Media to Increase Learning Motivation in Elementary School. Anatolian Journal of Education, 4(2), 53-60. https://doi.org/https://doi.org/10.29333/aje.2019.426a

Sugiyono. (2015). Metode Penelitian Pendidikan Pendekatan Kuantitatif, Kualitatif dan R\&D. Penerbit Alfabeta.

Tafonao, T. (2018). Peranan Media Pembelajaran Dalam Meningkatkan Minat Belajar Mahasiswa. Jurnal Komunikasi Pendidikan, 2(2), 103-114. https://doi.org/10.32585/jkp.v2i2.113

Tamrin, M., Azkiya, H., \& Sari, S. G. (2017). Problems Faced by the Teacher in Maximizing the Use of Learning Media in Padang. AL-TA'LIM JOURNAL, 24(1), 60-66. https://doi.org/https://doi.org/10.15548/jt.v24i1.262

Turmuzi, M., \& Dasing, A. S. H. (2021). Analisis Kesulitan Belajar Mahasiswa Secara Online ( E-Learning ) Selama Masa Pandemi Covid-19. EDUKATIF: Jurnal Ilmu Pendidikan, 3(3), 900-910. https://doi.org/https://doi.org/10.31004/edukatif.v3i3.482

Uno, W. A. (2021). Pengembangan Teknologi Pendidikan IPA Berbasis Multimedia dalam Meningkatkan Minat Belajar Siswa (N. L. H. Sholehah (ed.)). CV. Cahaya Arsh.

Yunitasari, R., \& Hanifah, U. (2020). Pengaruh Pembelajaran Daring terhadap Minat Belajar Siswa pada Masa COVID-19. EDUKATIF : JURNAL ILMU PENDIDIKAN, 2(3), 232-243.

https://doi.org/https://doi.org/10.31004/edukatif.v2i3.142 